\title{
Radar rainfall estimates in an alpine environment using inverse hydrological modelling
}

\author{
A. Marx ${ }^{1}$, H. Kunstmann ${ }^{1}$, A. Bárdossy ${ }^{2}$, and J. Seltmann ${ }^{3}$ \\ ${ }^{1}$ Karlsruhe Research Center, Institute for Meteorology and Climate Research, Garmisch-Partenkirchen, Germany \\ ${ }^{2}$ University of Stuttgart, Institute of Hydraulic Engineering, Germany \\ ${ }^{3}$ German Weather Service, Meteorological Observatory Hohenpeissenberg, Germany
}

Received: 23 January 2006 - Revised: 22 May 2006 - Accepted: 3 July 2006 - Published: 26 September 2006

\begin{abstract}
The quality of hydrological modelling is limited due to the restricted availability of high resolution temporal and spatial input data such as temperature, global radiation, and precipitation. Radar-based rain measurements provide good spatial information. On the other hand, using radar data is accompanied by basic difficulties such as clutter, shielding, variations of $Z / R$-relationships, beam-resolution and attenuation. Instead of accounting for all errors involved separately, a robust $Z / R$-relationship is estimated in this study for the short range (up to $40 \mathrm{~km}$ distance) using inverse hydrological modelling for a continuous period of three months in summer 2001. River gauge measurements from catchment sizes around $100 \mathrm{~km}^{2}$ are used to estimate areal precipitation and finally $Z / R$-relationships using a calibrated hydrological model. The study is performed in the alpine Ammer catchment with very short reaction times of the river gauges to rainfall events.
\end{abstract}

\section{Introduction}

Catchments in mountainous regions often have short response times of river discharges to rainfall events. Rainfallrunoff modelling requires high quality estimates of areal precipitation. Radar rainfall data provides good spatial information in a high temporal resolution while it is difficult to estimate absolute rainfall intensities. Ground based gauge measurements give accurate information about the accumulated rain at only one point. A comparison of radar-based and rain gauge measurements reveals differences due to different measurement principles. This study presents a method to estimate hourly rainfall intensities from radar reflectivities using inverse hydrological modelling. Measured river runoff is used as a measure for the areal precipitation, using the calibrated model WaSiM to calculate the missing terms of the hydrological cycle.

\section{The testcase}

This study is performed in the Ammer catchment in the southern Bavarian Alps and alpine forelands, Germany. The catchment size is $709 \mathrm{~km}^{2}$ up to the inflow into Lake Ammersee. The highest elevation is $2185 \mathrm{~m}$ a.s.l. (Kreuzspitze) in the Ammergau Alps, the outflow into Lake Ammersee is the lowest part within the catchment (533 ma.s.1.). Due to the complex orography and heterogeneity in topography, the catchment is characterised by big north-southerly differentiations in soils, landuse, and climate. Long term mean annual precipitation in the northern part of the catchment is around $1100 \mathrm{~mm} / \mathrm{a}$ while the southern part with the summits of the Ammer Alps receives more than 2000 mm/a. Maximum precipitation is in summer. The mean annual temperature is around 7-8 $\circ \mathrm{C}$ in the alpine forelands and $4.5 \circ \mathrm{C}$ in the southern part of the catchment. The work focuses on the period summer 2001 to minimize uncertainties in the hydrological modelling and radar data processing due to snowfall. Within the basin, six river gauges were available in 2001. Geographical input data (elevation from interferometric ERS-data and digital maps, landuse from Landsat-TM fuzzy logic classification, and soil classes from Bavarian Bodenguetekarte) were obtained from the RAPHAEL Project (RAPHAEL, 2000) in which the runoff and atmospheric processes for flood hazard forecasting and control was investigated.

Correspondence to: A. Marx

(andreas.marx@imk.fzk.de)

Published by Copernicus GmbH on behalf of the European Geosciences Union. 


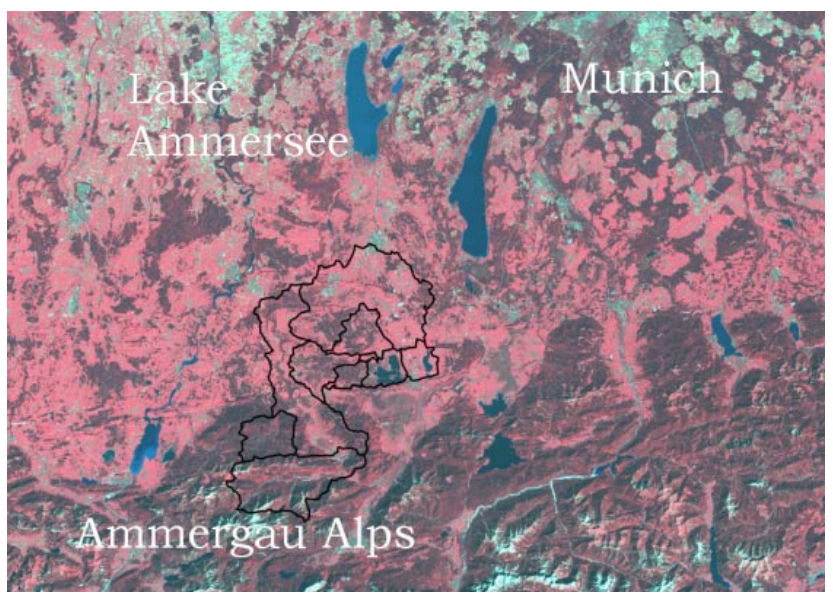

Fig. 1. Location of the Ammer basin in southern Germany (black outlines show the modelled subbasins).

\section{Methods}

\subsection{Estimation of rainfall rate with radar data}

Rainfall intensities $R$ can be estimated from radar reflectivities $Z$ using the simple power law $Z / R$ relationship:

$Z=a R^{b}$

( $Z$ in $\mathrm{mm}^{6} \mathrm{~m}^{-3}, R$ in $\mathrm{mm} / \mathrm{h}$ ). $\mathrm{Z}$ values are normally given in dBZ units. First theoretical studies were shown by Marshall and Palmer (1948) assuming Rayleigh scattering and an exponential drop-size distribution resulting in $Z=296 R^{1.47}$. In the following years, various $Z / R$-relations have been proposed. They show a wide range of coefficient $a$. Wu and Tokay (2003) concluded that variations from $b=1.31$ can be ascribed to measurement uncertainties from a synthetical experiment. Doelling et al. (1998) proposed that b can be set to 1.5 for mid-latitude rain events based on data from a seven year period and that only a varies from event to event. The wide range of event-to-event varying $Z / R$-relationships suggests that standard relationships may hardly be relied on in operational use. Calibration techniques using rain gauge measurements are widely applied (e.g. Chumchean et al., 2006; RADOLAN, 2004; Fulton et al., 1998; Rosenfeld et al., 1994; Collier et al., 1983). When comparing with rain gauge measurements, it must be considered that residual errors occur due to different measurement principles: accumulated point measurements from the surface are compared to instantaneous rainfall in volumes of the order of $1 \mathrm{~km}^{3}$ at some height above the ground (Chumchean et al., 2006; Gabella and Amitai, 2000). Germann and Joss (2000) point out that the representativeness of a point measurement strongly depends on the type of precipitation, on the integration time and on the location.

\subsection{The distributed hydrological model WaSiM}

The Water balance Simulation Model WaSiM (Schulla and Jasper, 2000) uses a mixture of conceptual approaches and physically based algorithms to describe hydrological processes. Infiltration of water into the soil and the surface runoff generation is computed after Green and Ampt (1911) using the two step model approach after Peschke (1987). The calculation of the vertical water fluxes in the unsaturated zone is done by the discrete Richards Equation. Soil moisture content is parameterized considering suction head and hydraulic conductivity according to van Genuchten (1976). Interflow is generated in defined different soil layers depending on drainable water content, suction, the hydraulic conductivity and gradient. Surface runoff is routed using a subdivision of the basin into flow time zones. Interception is considered using a simple bucket approach with a leaf area index dependent storage capacity. Evapotranspiration is calculated following the approach of Penman-Monteith (Monteith, 1975). WaSiM contains a simple 2-D groundwater model which is dynamically coupled to the unsaturated zone.

\section{Model setup and calibration}

The hydrological simulations for the Ammer catchment (Fig. 1) have been applied with a spatial resolution of $100 \times 100 \mathrm{~m}^{2}$ and a temporal resolution of one hour. Hydrological modelling requires besides high quality input data also knowledge about optimal parameter settings. Before this background, WaSiM was calibrated intensively for summer 2001 using the experience from Krause (2003) and Mayr (2004) and meteorological data from 15 stations around the basin. Horizontal interpolation of this data has been done through inverse distance weighting. In case of temperature, a combination with altitude dependent regression has been performed. Although the number of stations has been small and therefore the quality of the meteorological input data has been limited, the calibration results show good accordance to river gauge measurements (Fig. 3). The simulation results are better in low flow then in flood periods. This occurs because the calculated river discharges depend mainly on the parameter fit in low flow periods. In flood periods, the simulation results are additionally influenced by the quality of meteorological input data. Table 1 gives the location and the calibration results for the six river gauges. It must be noted the discharge of gauge Oberammergau is influenced by the karstic underground in the Linder valley. Due to the calibration problems at gauge Oberhausen caused by the influence of Lake Staffelsee, this subcatchment has not been used for the further computations. 
Table 1. Subbasin characteristics in the Ammer catchment and performance of calibration results (NS, Nash and Sutcliffe, 1970) for summer 2001.

\begin{tabular}{llccc}
\hline & River gauge & Altitude [m a.s.l.] & Area $\left[\mathrm{km}^{2}\right]$ & NS \\
\hline (1) & Oberammergau & 831 & 114 & 0.1628 \\
$(2)$ & Halbammer & 849 & 43.5 & 0.5431 \\
$(3)$ & Obernach & 652 & 51.5 & 0.6365 \\
$(4)$ & Oberhausen & 585 & 117 & -0.8381 \\
$(5)$ & Peissenberg & 592 & 294 & 0.9554 \\
$(6)$ & Weilheim & 550 & 601 & 0.9481 \\
\hline
\end{tabular}

\section{Estimation of a $Z / R$-relationship using inverse hydro- logical modelling}

The German Weather Service-Project RADOLAN (2004) investigated and established an operational method to adjust radar rainfall intensities online using ground-based point measurements of rainfall. As intermediate step, the overall $Z / R$ relationship was differentiated into three piecewise linear parts depending on the absolute reflectivity values. This division was done (1) to reduce the overestimated rainfall from strong convective events and (2) to raise the precipitation amount calculated from homogeneous, stratiform rainfall events. First results showed an improvement in comparison to the standard uniform $Z / R$-relationship used at the German Weather Service $\left(Z=256 R^{1.42}\right)$. A simplified version of this improved $Z / R$-relationship for three reflectivity ranges with

$$
\begin{array}{rr}
Z=125 R^{1.4} & <36.5 d B Z \\
Z=200 R^{1.6} & 36.5 \cdots 44 d B Z \\
Z=77 R^{1.9} & >44 d B Z
\end{array}
$$

was applied to calculate rainfall intensities using the data from the radar at Meteorological Observatory Hohenpeissenberg. This device faces the advantage of being installed at $988 \mathrm{~m}$ a.s.l. on top of Mount Hohenpeissenberg, therefore ground clutter is reduced to a minimum. Attenuation has been neglected because the radar device is situated next to the Ammer catchment (Fig. 2).

The new approach chosen in this study is to estimate parameters a,b and the changeovers $\mathrm{c} 1, \mathrm{c} 2$ between the three parts via comparison of observed runoff $Q_{\text {obs }}$ and radar data driven simulated runoff $Q_{\text {sim }}$. The optimisation problem can be formulated with mean observed discharge $\overline{Q_{\text {obs }}}$ as

$$
1-\frac{\sum_{i=1}^{n}\left(Q_{\mathrm{obs}}-Q_{\mathrm{sim}}\left[R\left(Z, a_{j}, b_{j}, c 1, c 2\right]\right)^{2}\right.}{\sum_{i=1}^{n}\left(\overline{Q_{\mathrm{obs}}}-Q_{\mathrm{sim}}\left[R\left(Z, a_{j}, b_{j}, c 1, c 2\right]\right)^{2}\right.} \stackrel{!}{\Rightarrow} \min
$$

for each branch $j=(1,2,3)$ of the split $Z / R$-relationship and for every subcatchment. In each optimization step, two parameters have been optimised at the same time. It was taken into account that higher dBZ-values always result in higher

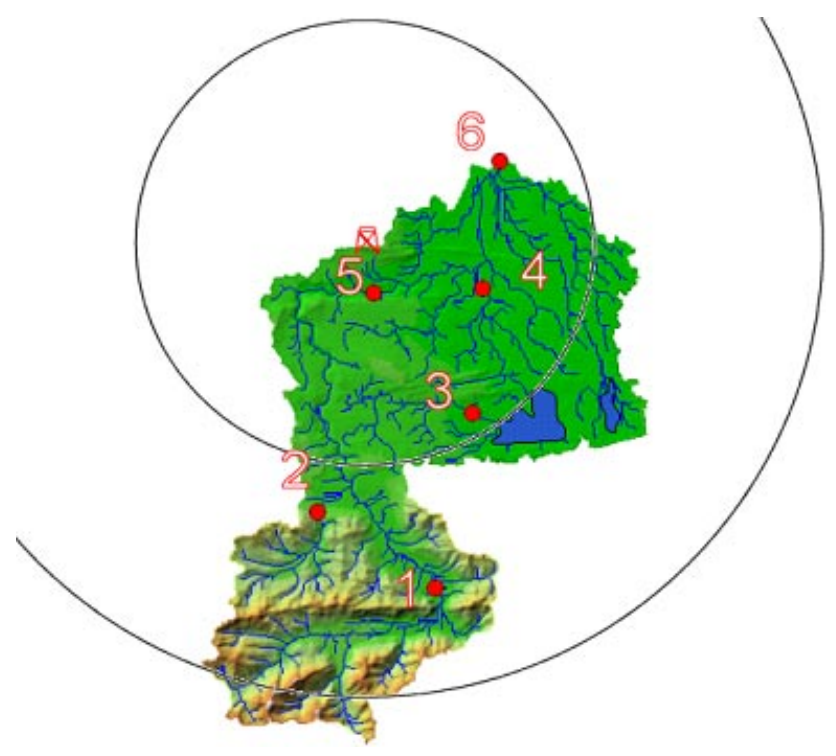

Fig. 2. Location of the six river gauges (red circles) and radar site at Hohenpeissenberg with range rings at 15 and $30 \mathrm{~km}$; Numbers refer to gauges in Table 1 .

rainfall intensities. The parameter estimation was applied on five subcatchments. It was repeated using different starting values for two times and resulted finally in:

$$
\begin{array}{rr}
Z=104 R^{1.43} & <36.5 d B Z \\
Z=146 R^{1.57} & 36.5 \cdots 45 d B Z \\
Z=93 R^{1.63} & >45 d B Z
\end{array}
$$

A comparison of the hydrological simulation results is given in Table 2. The use of $Z=256 R^{1.42}$ caused an underestimation of areal rainfall and therefore an underestimation of the simulated discharges. It must be noted that the results of the subcatchment Oberammergau in the Ammergau Alps improved in comparison to simulations using raingauge data. This may be explained due to the fact that no raingauge data has been available for that mountainous region, and that raingauges located north and south of the Ammergau Alps have been used for the statistical interpolation. A comparison of simulated river discharges using rainfall data estimated by the simplified version of the method proposed by RADOLAN (2004) to observed river discharges shows good accordance. Even if this method is only an intermediate step in the computation of areal precipitation at the German Weather Service, the results of this study show that the estimation of areal radar precipitation outperforms interpolated raingauge data. Runoff simulations with the new found split three-part $Z / R$-relationship show overall the best results. 
Table 2. Performance of river runoff simulations using different areal rainfall estimates for summer 2001.

\begin{tabular}{lcccc}
\hline River gauge & $\begin{array}{c}\text { IDW } \\
\text { from } \\
\text { raingauge data }\end{array}$ & $\begin{array}{c}\text { Radar rainfall, } \\
\text { Z=256R1.42 }\end{array}$ & $\begin{array}{c}\text { Radar rainfall, } \\
\text { Eq. (2), } \\
\text { (simplified RADOLAN) }\end{array}$ & $\begin{array}{c}\text { Radar rainfall, } \\
\text { Eq. (4), } \\
\text { calibrated using river discharge }\end{array}$ \\
\hline Oberammergau & 0.1628 & 0.3884 & 0.7869 & 0.7689 \\
Halbammer & 0.5431 & 0.2920 & 0.5468 & 0.5729 \\
Obernach & 0.6365 & 0.4055 & 0.5797 & 0.6283 \\
Peissenberg & 0.9554 & 0.9114 & 0.9650 & 0.9662 \\
Weilheim & 0.9481 & 0.8742 & 0.9764 & 0.9767 \\
\hline
\end{tabular}
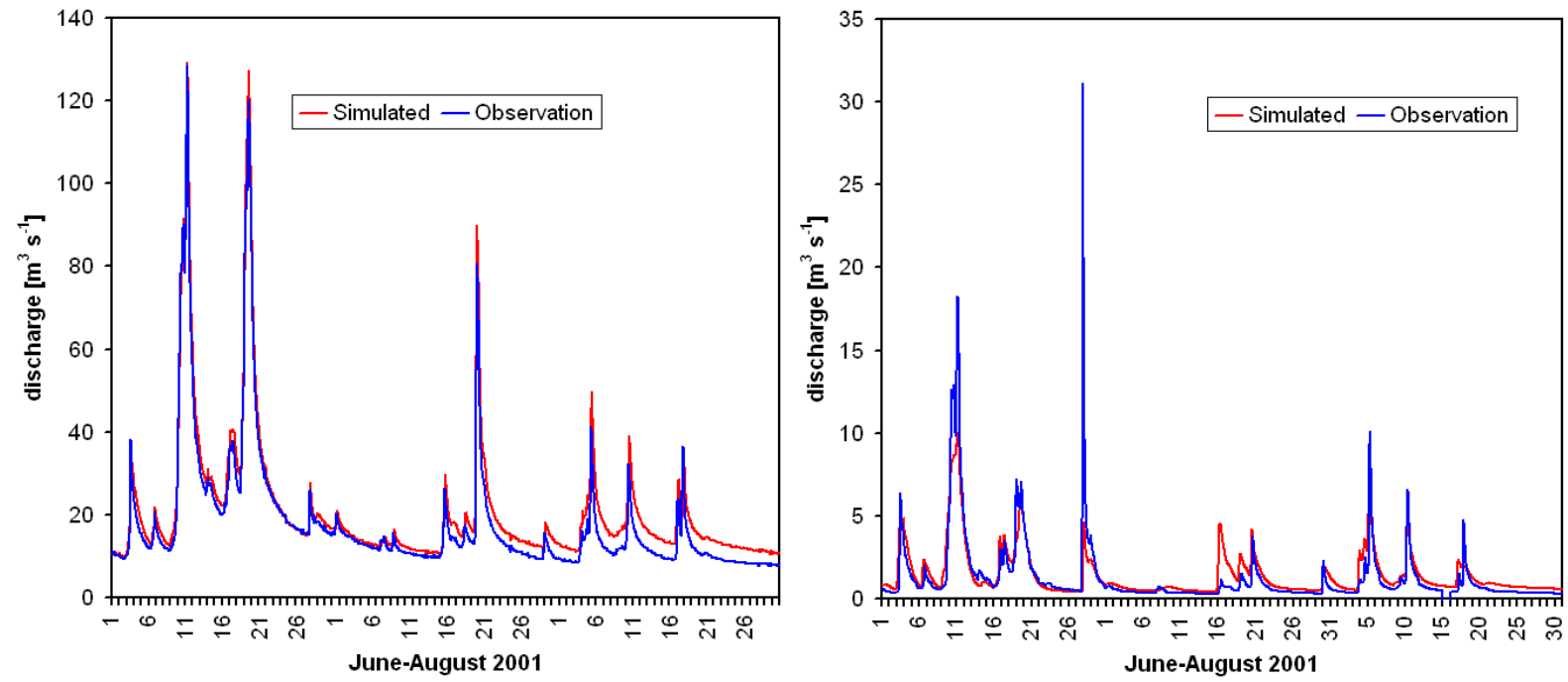

Fig. 3. WaSiM-Parameter Calibration results at gauge Weilheim (left) and gauge Obernach (right side) using interpolated raingauge measurements from 15 sites.

\section{Summary and conclusions}

For this study, hourly areal precipitation was estimated using

1. statistically interpolated raingauge data,

2. estimated radar rainfall from a standard $Z / R$-relationship

3. radar rainfall from improved $Z / R$-relationships which are divided into three parts, and

4. a calibrated version of (3) using measured river discharges and a calibrated hydrological model.

The distributed hydrological model WaSiM was adapted to the alpine Ammer catchment and calibrated using statistically interpolated raingauge data from 15 stations. The study has shown that radar data can be used to improve river discharge simulations over a continuous period of three months in comparison to raingauge data. On the other hand side, measured river discharges are used to estimate areal precipitation using a calibrated hydrological model. Rainfall runoff modelling for a three month period in summer 2001 using radar data estimated with $Z=256 R^{1.42}$ showed an underestimation of areal precipitation and therefore an underestimation of simulated runoff. The results using a simplified version of the relationship given in RADOLAN (2004) showed a slight underestimation of total areal rainfall sum in summer 2001 in comparison to interpolated raingauge data, but outperformed results of the hydrological simulations. The best results have been obtained with the new found three-part $Z / R$ relationship.

Acknowledgements. This work was partially performed under the framework of the Centre of Numerical Environmental Simulation at the University of Augsburg and funded by the Bavarian High Tech Initiative.

Edited by: R. Barthel, J. Götzinger, G. Hartmann, J. Jagelke, V. Rojanschi, and J. Wolf

Reviewed by: anonymous referees 

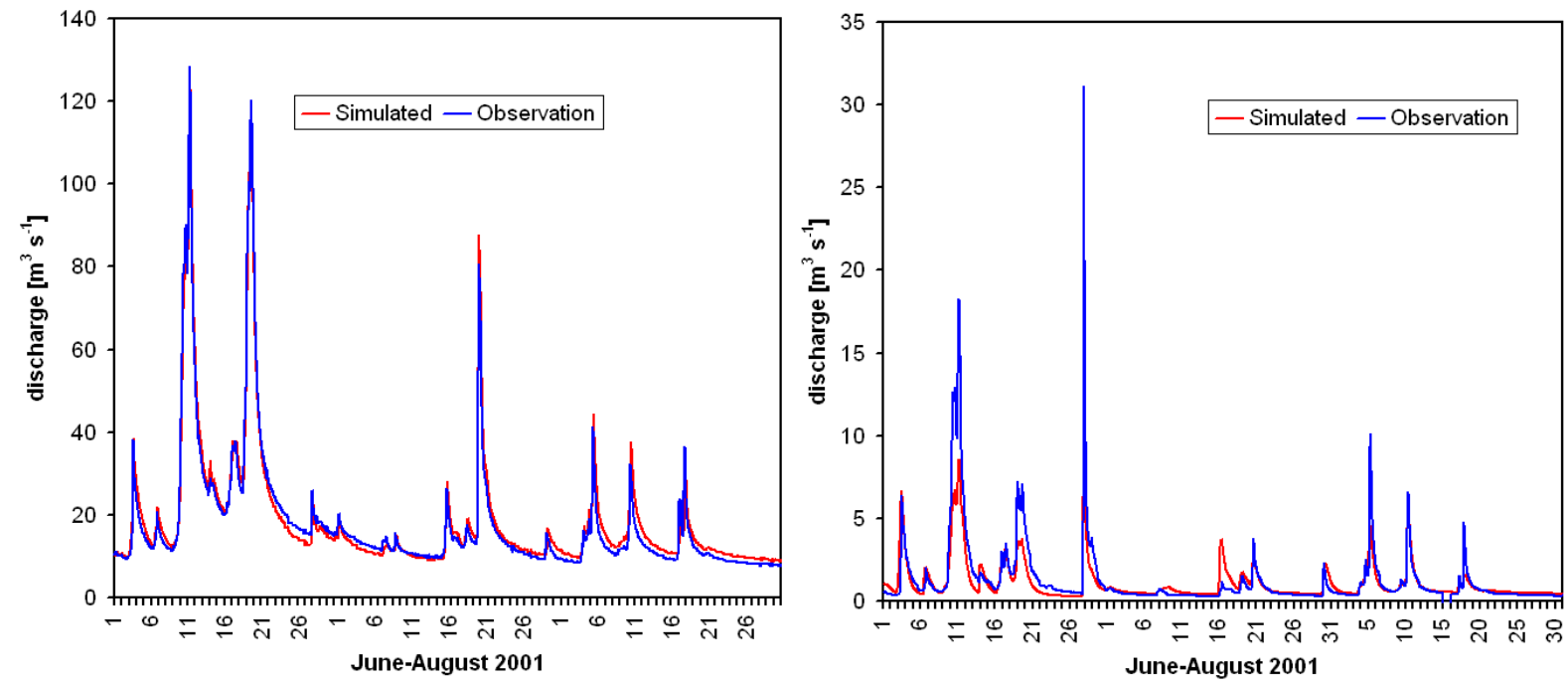

Fig. 4. Hydrological simulation results using the calibrated divided Z/R-relationship compared to Observations at gauge Weilheim ( left) and gauge Obernach (right side).

\section{References}

Chumchean, S., Seed, A., Shara, A.: Correcting of real-time radar rainfall bias using a Kalman filtering approach, J. Hydrol., 317, 123-137, 2006.

Collier, C. G., Larke, P., and May, B.: A weather radar correction procedure for real-time estimation of surface rainfall, Quat. J. Roy. Meteorol. Soc., 109, 589-608, 1983.

Doelling, I. G., Joss, J., and Riedl, J..: Systematic Variations of Z-R relationships from drop size distributions measured in northern Germany during 7 years, Atmos. Res., 47-48, 635-649, 1998.

Fulton, R. A., Breidenbach, J. P., Seo, D.-J., Miller, D. A., and O'Bannon, T.: The WSR-88D rainfall algorithm, Wea. Forecast., 13, 388-395, 1998.

Gabella, M. and Amitai, E.: Radar rainfall estimates in an alpine environment using different gage-adjustment techniques, Phys. Chem. Earth (B), 25(10-12), 927-931, 2000.

Green, W. H. and Ampt, GA.: Studies on Soil Physics: I. The flow of air and water through soils, J. Agric. Sci., 4, 1-24, 1911.

Joss, J. and German, U.: Solutions and problems when applying qualitative and quantitative information from weather radar, Phys. Chem. Earth (B), 25(10-12), 837-841, 2000.

Krause, J.: Inverse hydrologische Modellierung fr das Einzugsgebiet der Ammer mittels WaSiM-ETH und PEST, University of Trier, master thesis (in german), 135 p., 2003.

Marshall, J. S. and Palmer, W. McK: The distribution of raindrops with size, J. Meteorol., 5, 165-166, 1948.
Mayr, S.: Inverse flchendifferenzierte hydrologische Modellierung des Ammer-Einzugsgebietes mittels Kombination von Grundund Oberflchenwasserdaten, University of Augsburg, master thesis (in german), 132 p., 2004.

Monteith, J. L.: Vegetation and the atmosphere, Vol. 1, Principles, Academic Press, London, 1975.

Nash, J. E and Sutcliffe, I. V.: River flow forecasting through conceptual models, J. Hydrol., 273, 282-290, 1970.

Peschke, G.: Soil Moisture and Runoff Components from a Physically Founded Approach, Acta hydrophysica, 31(3/4), 191-205, 1987.

RADOLAN (Radar Online Adjustment), German Weather Service, Department for Hydrometeorology, http: //www.dwd.de/de/wir/Geschaeftsfelder/Hydrometeorologie/ a_href_pages/RADOLAN/radolan-online.htm (in german), 2004.

RAPHAEL: Runoff and Atmospheric Processes for Flood Hazard Forecasting and Control, EU project ENV4-CT97-0552, 2000.

Rosenfeld, D., Wolff, D. B., and Amitai, E.: The Window Probability Matching Method for rainfall measurements with radar, J. Appl. Meteor., 34, 212-223, 1994.

Schulla, J. and Jasper, K.: Model description WaSiM-ETH, Institute for Geography, ETH, Zürich, 167 pp., 2000.

Van Genuchten, M. T.: A Closed-Form Equation for Predicting the Hydraulic Conductivity of Unsaturated Soils, Soil Sciences Society of American Journal, 44(5), 892-898, 1976.

$\mathrm{Wu}, \mathrm{Z}$. J. and Tokay, A.: Spurious power-law relations among rainfall and radar parameters, Quat. J. Roy. Meteorol. Soc., 128, 2045-2058, 2003. 